\title{
HUBUNGAN TIMBAL DARAH TERHADAP KELAINAN SEL DARAH PADA ANAK JALANAN DI KOTA YOGYAKARTA
}

\author{
Hieronymus Rayi Prasetya ${ }^{1^{*}}$, Dian Wuri Astuti², Titah Dewi Rahardian ${ }^{3}$ \\ D3 Teknologi Laboratorium Medis STIKES Guna Bangsa Yogyakarta \\ * e-mail: rayi.prasetya@gmail.com
}

\begin{abstract}
Introduction : Increasing ownership of motorized vehicles will be accompanied by increased use of fuel followed by high air pollution (lead). Pb can cause erythrocyte hemolysis and inhibit the formation of hemoglobin. This causes a decrease in the life span of erythrocytes and increases the fragility of erythrocyte membranes. Lead poisoning in the blood is characterized by basophilic stippling in erythocytes. Street musicians who do their work on the edge of the road (traffic light) are a group of populations that are susceptible to $\mathrm{Pb}$ poisoning, due to exposure to vehicle fumes every day as well as low knowledge about health conditions and the use of personal protective equipment (masks).

Aims : This study aims to determine the effect of lead exposure on quantity (amount) and quality of blood cells (morphology).

Method : The study was conducted by survey method, questionnaire and laboratory examination (blood lead, complete blood count, blood cell morphology). The data obtained were 32 samples analyzed using Spearman nonparametric with a confidence level of $95 \%$.

Results : The results of blood lead examination obtained 100\% of respondents had normal lead levels $(<100 \mu \mathrm{g} / \mathrm{L})$. The results also showed no association between blood lead with hemoglobin, erythrocytes, platelets, leukocytes, hematocrit, neutrophils, lymphocytes, monocytes, eosinophils, and basophils. Based on the results of morphological examination of erythrocytes, it shows that all respondents did not experience erythrocyte size, color and shape abnormalities and found no basophilic stippling.

Conclutions : There is no relationship between blood lead and the quantity of blood cells. Morphological examination of blood cells found no cell abnormalities and found no basophilic stippling. Despite being exposed to vehicle fumes every day, respondents of street children did not experience lead poisoning and did not experience blood cell disorders.
\end{abstract}

Keywords: Lead, Complete blood count, Morphology Cell, Basophilic stippling

\section{PENDAHULUAN}

Aktivitas transportasi khususnya

kendaraan bermotor merupakan sumber

utama pencemaran udara di daerah

perkotaan. Kendaraan bermotor

menghasilkan $\quad 85 \%$ dari seluruh

pencemaran udara yang terjadi. Emisi yang

dikeluarkan kendaraan bermotor

menghasilkan berbagai polutan seperti

Karbon Monoksida (CO), Hidrokarbon

(HC), Oksida Nitrogen (NOx), Oksida
Sulfur (SOx), partikulat dan Timbal $(\mathrm{Pb}){ }^{1}$

Timbal merupakan salah satu jenis logam berat alamiah. Peningkatan aktivitas manusia, seperti penggunaan dalam bahan bakar minyak dan pemakaian timbal untuk kebutuhan komersial yang meluas telah menyebabkan timbal menyebar di lingkungan. ${ }^{2}$

Timbal $(\mathrm{Pb})$ dari kendaraan bermotor berasal dari hasil pembakaran

Meditory | ISSN Online : 2549-1520, ISSN Cetak : 2338 - 1159, Vol. 9, No. 1, Juni 2021 
Prasetya, H.R., dkk: Hubungan Timbal Darah terhadap Kelainan Sel Darah pada Anak Jalanan di Kota Yogyakarta

bahan tambahan (aditive) $\mathrm{Pb}$ pada kendaraan berbahan bakar bensin yang akan menghasilkan emisi $\mathrm{Pb}$ in organik. $\mathrm{Pb}$ dalam bentuk senyawa alkyl-pb digunakan sebagai campuran bensin yang berfungsi untuk meningkatkan bilangan oktan bahan bakar. Logam berat $\mathrm{Pb}$ yang bercampur dengan bahan bakar dan oli, melalui proses di dalam mesin, menghasilkan logam berat $\mathrm{Pb}$ yang akan keluar melalui knalpot bersama dengan gas buang lainnya. ${ }^{3}$

Pada tahun 2012, Daerah Istimewa Yogyakarta terdapat 152.178 mobil penumpang, 11.019 mobil bus, 48.508 mobil barang, 1.537.534 sepeda motor dan 499 kendaraan khusus. ${ }^{4}$ Pada tahun 2015 terjadi peningkatan jumlah kendaraan menjadi 206.658..$^{5}$ Meningkatnya jumlah kendaraan setiap tahunnya maka berpotensi meningkatnya pencemaran $\mathrm{Pb}$ ke udara akibat dari meningkatnya pemakaian bahan bakar kendaraan. Konsentrasi $\mathrm{Pb}$ dipengaruhi oleh jumlah kendaraan berbahan bakar bensin yang melintas sebesar $79-97 \% .^{6}$

Timbal yang masuk ke dalam tubuh dapat menimbulkan keracunan. Tanda dan gejala keracunan timbal termasuk sembelit, sakit perut, anemia, gagal ginjal, sistem kekebalan tubuh yang lemah, gangguan fungsi sistem saraf pusat, berat badan lahir rendah, kelahiran mati dan keguguran, dan kelahiran prematur. Pada anak-anak, gangguan pertumbuhan adalah komplikasi utama keracunan timbal lainnya. ${ }^{7,8}$
$\mathrm{Pb}$ dapat menyebabkan hemolisa eritrosit dan menghambat pembentukan hemoglobin.Pb menyebabkan defisiensi enzim G-6PD dan penghambatan enzim pirimidin-5'-nukleotidase. Hal ini menyebabkan turunnya masa hidup eritrosit dan meningkatkan kerapuhan membran eritrosit, sehingga terjadi penurunan jumlah eritrosit. Defisiensi enzim ini secara herediter ditandai dengan basophilic stippling pada eritosit. Keberadaan $\mathrm{Pb}$ di dalam eritrosit menyebabkan terganggunya pembentukan hemoglobin dalam eritrosit. Pada sediaan hapus darah tepi keracunan $\mathrm{Pb}$ dapat dilihat dengan adanya benda inklusi eritrosit (basophilic stippling). Basophilic stippling adalah sisa agregat dari gagalnya pembentukan hemoglobin. ${ }^{9}$

Anak jalanan yang melakukan pekerjaannya di pinggir jalan raya (traffic light) merupakan kelompok populasi yang rentan terhadap keracunan $\mathrm{Pb}$. $\mathrm{Pb}$ yang ada dalam asap kendaraan bermotor akan sangat mudah terhirup bagi kelompok populasi ini, karena rendahnya pengetahuan tentang kondisi kesehatan dan penggunaan Alat Pelindung Diri (masker).

\section{TUJUAN PENELITIAN}

Penelitian ini bertujuan untuk mengetahui hubungan timbal darah terhadap kelainan sel darah pada anak jalanan di Kota Yogyakarta. 
Prasetya, H.R., dkk: Hubungan Timbal Darah terhadap Kelainan Sel Darah pada Anak Jalanan di Kota Yogyakarta

\section{METODE PENELITIAN}

Penelitian dilakukan pada bulan Maret-Oktober 2018 dengan melakukan survei terhadap responden di kawasan trafficlight di 14 Kecamatan yang berada di Kota Yogyakarta. Teknik pengambilan sampel yang dilakukan adalah purposive sampling, dengan kriteria anak jalanan yang berada di trafficlight wilayah Kota Yogyakarta saat pengambilan sampel dan bersedia untuk dijadikan responden. Responden anak jalanan (pengamen) yang diperoleh sebanyak 32 sampel. Responden diberikan kuisioner untuk mengetahui karakteristik responden. Sampel darah yang diperoleh diperiksa timbal darah, darah lengkap dan pemeriksaan morfologi sel eritrosit (ukuran, warna, bentuk, dan basophilic stippling). Timbal darah diperiksa menggunakan Spektrofotometer serapan atom, Darah lengkap diperiksa menggunakan Hematology Analyzer,
Morfologi eritrosit diperiksa menggunakan hapusan darah. Data yang diperoleh dianalisa menggunakan uji nonparametrik Spearman.

\section{HASIL DAN PEMBAHASAN}

Kuisioner yang diisi oleh responden berfungsi untuk mengetahui gambaran dan informasi mengenai karakteristik responden dan faktor-faktor yang kemungkinan berkaitan dengan proses pembentukan sel-sel darah (morfologi eritrosit). Hasil kuisioner (Tabel 1) menunjukan karakteristik 93,8 \% laki-laki, 71,9\% merupakan usia remaja akhir, 50\% bekerja 1-5 tahun, 40,6\% terpapar asap kendaraan selama 3,1-5 jam perhari, 100\% memiliki pola makan tidak teratur, 96,9\% memiliki pola tidur tidak teratur, 59,4\% tidak memiliki kebiasaan mengkonsumsi alkohol, dan $81,3 \%$ memiliki kebiasaan merokok. 
Prasetya, H.R., dkk: Hubungan Timbal Darah terhadap Kelainan Sel Darah pada Anak Jalanan di Kota Yogyakarta

Tabel 1. Kadar timbal berdasarkan karakteristik responden

\begin{tabular}{|c|c|c|c|c|c|}
\hline No & $\begin{array}{l}\text { Karakteristik } \\
\text { responden }\end{array}$ & Kategori & Frekuensi & $\begin{array}{l}\text { Persentase } \\
(\%)\end{array}$ & $\begin{array}{l}\text { Rata-rata } \\
\text { kadar Pb } \\
(\mu \mathrm{g} / \mathrm{L})\end{array}$ \\
\hline \multirow[t]{2}{*}{1} & \multirow[t]{2}{*}{ Jenis Kelamin } & Laki-laki & 30 & 93,8 & 28,6 \\
\hline & & Perempuan & 2 & 6,3 & 18,1 \\
\hline \multirow[t]{4}{*}{2} & \multirow[t]{4}{*}{ Usia } & $\begin{array}{l}\text { Remaja awal (12-16 } \\
\text { tahun) }\end{array}$ & 1 & 3,1 & 28,1 \\
\hline & & $\begin{array}{l}\text { Remaja akhir (17-25 } \\
\text { tahun) }\end{array}$ & 23 & 71,9 & 29,2 \\
\hline & & $\begin{array}{l}\text { Dewasa awal (26-35 } \\
\text { tahun) }\end{array}$ & 7 & 21,9 & 27,8 \\
\hline & & $\begin{array}{l}\text { Dewasa akhir (36-45 } \\
\text { tahun) }\end{array}$ & 1 & 3,1 & 0,016 \\
\hline \multirow[t]{4}{*}{3} & \multirow[t]{4}{*}{ Lama Bekerja } & $>5$ tahun & 2 & 6,3 & 38,7 \\
\hline & & 1-5 tahun & 16 & 50 & 26,8 \\
\hline & & $<1$ tahun & 7 & 21,9 & 21,8 \\
\hline & & Tidak menentu & 7 & 21,9 & 33,6 \\
\hline \multirow[t]{4}{*}{4} & \multirow{4}{*}{$\begin{array}{l}\text { Lama Terpapar Asap } \\
\text { kendaraan }\end{array}$} & $<3$ Jam & 5 & 15,6 & 20,8 \\
\hline & & $3,1-5$ jam & 13 & 40,6 & 22,1 \\
\hline & & $5,1-8$ jam & 11 & 34,4 & 30,8 \\
\hline & & $>8$ jam & 3 & 9,4 & 37,1 \\
\hline \multirow[t]{2}{*}{5} & \multirow[t]{2}{*}{ Pola Makan } & Teratur & 0 & 0 & - \\
\hline & & Tidak teratur & 32 & 100 & 27,9 \\
\hline \multirow[t]{2}{*}{6} & \multirow[t]{2}{*}{ Pola Tidur } & Teratur & 1 & 3,1 & 36,6 \\
\hline & & Tidak teratur & 31 & 96,9 & 27,7 \\
\hline \multirow[t]{2}{*}{7} & \multirow[t]{2}{*}{ Konsumsi Alkohol } & $\mathrm{Ya}$ & 13 & 40,6 & 30,2 \\
\hline & & Tidak & 19 & 59,4 & 26,4 \\
\hline \multirow[t]{2}{*}{8} & \multirow[t]{2}{*}{ Konsumsi Rokok } & $\mathrm{Ya}$ & 26 & 81,3 & 28,6 \\
\hline & & Tidak & 6 & 18,8 & 24,9 \\
\hline
\end{tabular}

Tabel 2. Hasil Pemeriksaan Timbal darah

\begin{tabular}{llllll}
\hline Parameter & Normal & $\begin{array}{l}\text { Lebih dari } \\
\text { Normal }\end{array}$ & $\begin{array}{l}\text { Nlai } \\
\text { tertinggi }\end{array}$ & $\begin{array}{l}\text { Nilai } \\
\text { terendah }\end{array}$ & Rata-rata \\
\hline Kadar Timbal Darah & $32(100 \%)$ & $0(0 \%)$ & 40,85 & 0,016 & 27,952 \\
\hline
\end{tabular}

Hasil pemeriksaan timbal darah pada anak jalanan menunjukan semua responden memiliki kadar timbal normal $(<100 \mu \mathrm{g} / \mathrm{L})$ dengan nilai tertinggi 40,85 $\mu \mathrm{g} / \mathrm{L}$ (Tabel 2). Meskipun memiliki kadar timbal yang normal, tetapi jika dilihat berdasarkan karakteristik responden, rata- rata kadar timbal bervariasi (Tabel 1). Berdasarkan Tabel 1, dapat terlihat bahwa anak jalanan yang memiliki lama bekerja lebih dari 5 tahun menunjukan nilai timbal yang lebih tinggi daripada yang bekerja kurang dari 5 tahun $(38,7 \mu \mathrm{g} / \mathrm{L})$. Hal yang sama juga terlihat dari karakteristik lama 
Prasetya, H.R., dkk: Hubungan Timbal Darah terhadap Kelainan Sel Darah pada Anak Jalanan di Kota Yogyakarta

terpapar asap kendaraan, semakin lama terpapar asap kendaraan maka kadar timbal darah semakin tinggi. Responden yang lama terpapar asap kendaraan lebih dari 8 jam memiliki rata-rata kadar timbal sebesar 37,1 $\mu \mathrm{g} / \mathrm{L}$. Kebiasaan mengkonsumsi alkohol dan merokok pada responden juga menunjukan kadar timbal yang lebih tinggi jika dibandingkan dengan responden yang tidak merokok dan tidak mengkonsumsi alkohol.

Penelitian lain pada tukang ojek menunjukan hasil yang berbeda, dimana $23 \%$ responden tukang ojek memiliki kadar timbal yang diatas toleransi, tetapi memiliki persamaan dimana kadar timbal lebih tinggi pada responden yang lebih lama bekerja dan lebih lama terpapar timbal. ${ }^{10}$ Penelitian lain juga menunjukan $86,7 \%$ penjual klepon menunjukan timbal darah yang melebihi batas. $^{11}$

Keterpaparan $\mathrm{Pb}$ yang dapat menimbulkan efek kronis hal ini dikarenakan $\mathrm{Pb}$ yang masuk melalui saluran pernapasan dan saluran pencernaan dapat masuk ke dalam darah akan menghambat sintesa heme sehingga akan mengurangi produksi $\mathrm{Hb}$ darah yang dapat berakibat pada munculnya gangguan kesehatan lainnya. Timbal dalam darah yang terakumulasi akan bersifat toksik. Meskipun jumlah timbal yang diserap oleh tubuh sangat sedikit namun dampaknya sangat berbahaya. Pada orang dewasa yang terpapar timbal $(\mathrm{Pb})$ dari lingkungan, konsentrasi timbal $(\mathrm{Pb})$ dalam darah tidak boleh melebihi $25 \mathrm{ng} / \mathrm{DL} .^{12,13}$

Paparan timbal pada anak-anak dapat menimbulkan efek keracunan yang lebih besar. Anak dengan Blood Lead Level (BLL) $>20 \mu \mathrm{g} / \mathrm{dL}$ dua kali lebih sering mengalami keluhan sistem gastrointestinal. BLL $>100 \mu \mathrm{g} / \mathrm{dL}$ menyebabkan disfungsi tubular ginjal. Timbal juga dapat menginduksi terjadinya sindrom Fanconi. Gejala susunan saraf pusat antara lain akibat edema serebral dan peningkatan tekanan intrakranial. Nyeri kepala, perubahan perilaku, letargi, edema papil, kejang, dan koma yang dapat mengakibatkan kematian jarang ditemukan pada anak dengan kadar timbal $>100 \mu \mathrm{g} / \mathrm{dL}$, tetapi pernah dilaporkan anak dengan BLL $<70 \mu \mathrm{g} / \mathrm{dL}$. Ensefalopati dapat terjadi pada anak dengan BLL >100 $\mu \mathrm{g} / \mathrm{dL}$. Pernah dilaporkan di Amerika Serikat (2006) anak meninggal dengan BLL $180 \mu \mathrm{g} / \mathrm{dL}$. Hiperaktif diamati pada anak-anak dengan BLL $>20 \mu \mathrm{g} / \mathrm{dL}$. Pada pasien yang lebih tua, timbal dapat menyebabkan neuropati perifer. Kadar timbal 10-14 $\mu \mathrm{g} / \mathrm{dL}$ sudah memerlukan edukasi dan diet dan memperhatikan lingkungan. ${ }^{2,14}$ Konsetrasi timbal dalam tubuh dengan kadar kadar timbal $(\mathrm{Pb}) 10 \mu \mathrm{g} / \mathrm{dL}$ mempunyai efek sedikit menurunkan IQ, pendengaran dan pertumbuhan menjadi terganggu. 
Prasetya, H.R., dkk: Hubungan Timbal Darah terhadap Kelainan Sel Darah pada Anak Jalanan di Kota Yogyakarta

Tabel 3. Hasil pemeriksaan Darah Lengkap

\begin{tabular}{lcccccc}
\hline Parameter & \multicolumn{2}{c}{ Rendah } & \multicolumn{2}{c}{ Normal } & \multicolumn{2}{c}{ Tinggi } \\
\cline { 2 - 7 } & $\mathrm{N}$ & $\%$ & $\mathrm{n}$ & $\%$ & $\mathrm{n}$ & $\%$ \\
\hline Hemoglobin & 1 & 3,1 & 28 & 87,5 & 3 & 9,4 \\
\hline Eritrosit & 1 & 3,1 & 29 & 90,6 & 2 & 6,3 \\
\hline Trombosit & 0 & 0,0 & 32 & 100,0 & 0 & 0,0 \\
\hline Leukosit & 0 & 0,0 & 31 & 96,9 & 1 & 3,1 \\
\hline Hematokrit & 4 & 12,5 & 25 & 78,1 & 3 & 9,4 \\
\hline Netrofil & 15 & 46,9 & 17 & 53,1 & 0 & 0,0 \\
\hline Limfosit & 4 & 12,5 & 20 & 62,5 & 8 & 25,0 \\
\hline Monosit & 0 & 0,0 & 26 & 81,3 & 6 & 18,8 \\
\hline Eosinofil & 5 & 15,6 & 9 & 28,1 & 18 & 56,3 \\
\hline Basofil & 0 & 0,0 & 5 & 15,6 & 27 & 84,4 \\
\hline
\end{tabular}

Berdasarkan Tabel 3, hasil pemeriksaan darah lengkap menunjukan sebagian besar berada pada rentang normal, kategori hasil rendah dan tinggi tidak banyak berperan karena tidak berkmakna secara klinis (hasil rendah atau tinggi tidak jauh dari rentang normal). Hal ini kemungkinan disebabkan karena kadar timbal dalam darah masih rendah sehingga belum mempengaruhi pembentukan sel-sel darah. Nilai kadar hemoglobin responden sebanyak 3,1\% dalam kategori rendah dan 9,4\% dalam kategori tinggi, hal tersebut belum tentu dipengaruhi oleh adanya timbal darah tetapi juga dapat dipengaruhi oleh kebiasaan merokok. Hal tersebut didukung dengan penelitian yang pernah dilakukan menunjukan bahwa tidak ada perbedaan kadar haemoglobin pada kelompok yang terpapar dan tidak terpapar timbal wilayah Jakarta Selatan. Kadar hemoglobin cenderung dipengaruhi oleh kebiasaan merokok. ${ }^{15,16}$
Meskipun hasil pemeriksaan darah lengkap menunjukan sebagian besar hasil pemeriksaan berada pada rentang normal, tetapi paparan timbal tetap berbahaya bagi tubuh. Hasil normal disebabkan oleh hasil pemeriksaan kadar timbal darah yang normal (tertinggi 40,85 $\mu \mathrm{g} / \mathrm{L}$ ), sehingga efek paparan timbal tersebut belum bisa mempengaruhi kelainan sel-sel darah dalam tubuh. Efek pertama keracunan timbal kronis sebelum mencapai target organ adalah adanya gangguan sintesis hemoglobin sehingga kadar hemoglobin menurun. ${ }^{17}$ Timbal menyebabkan 2 macam anemia, yang sering disertai dengan eritrosit berbintik basofilik. Dalam keadaan keracunan timbal akut terjadi anemia hemolitik, sedangkan pada keracunan timbal yang kronis terjadi anemia mikrositik hipokromik, hal ini karena menurunnya masa hidup eritrosit akibat interfensi logam timbal dalam sintesis 
Prasetya, H.R., dkk: Hubungan Timbal Darah terhadap Kelainan Sel Darah pada Anak Jalanan di Kota Yogyakarta

haemoglobin dan juga terjadi peningkatan korproporfirin dalam urin. ${ }^{18}$

Timbal mengganggu sistem sintesa $\mathrm{Hb}$ dengan jalan menghambat konversi Delta Aminolevulinic Acid (Delta ALA) menjadi porphobilinogen dan juga menghambat korporasi dari $\mathrm{Fe}$ ke dalam protophorpirin $I X$ untuk membentuk $\mathrm{Hb}$ dengan jalan menghambat enzim Delta Aminolevulinic Acid Dehidrase (delta ALAD) dan ferroketalase. Hal ini mengakibatkan meningkatnya ekskresi koprotophorpirin dalam urin dan delta ALA serta menghambat sintesa $\mathrm{Hb}$. Timbal masuk ke dalam darah menempel pada eritrosit, timbal bersifat perusak sehingga timbal yang menempel pada eritrosit akan membuat eritrosit lisis/hancur sebelum waktunya regenerasi. Sifat kerusakan timbal bersifat fluktuatif sesuai dengan intensitas paparan dan waktu regenerasi eritrosit, walaupun disisi lain ketika paparan terus menerus akan menyebabkan timbal terus masuk ke dalam darah mengikuti sirkulasi darah ke seluruh tubuh dan mengendap di organ yang lain seperti tulang sumsum dan terakumulasi, akan tetapi asupan gizi atau nutrisi yang cukup mampu berperan dalam pembuatan eritrosit yang baru menggantikan eritrosit yang lisis akibat timbal. ${ }^{19}$

Tabel 4. Hasil Pemeriksaan Morfologi eritrosit ${ }^{20}$

\begin{tabular}{llll}
\hline Karakteristik & Kategori & Jumlah & Persentase (\%) \\
\hline \multirow{2}{*}{ Ukuran } & Mikrositik & 0 & 0,0 \\
\cline { 2 - 4 } & Normositik & 32 & 100,0 \\
\cline { 2 - 4 } & Makrositik & 0 & 0,0 \\
\hline \multirow{2}{*}{ Warna } & Hipokromik & 0 & 0,0 \\
\cline { 2 - 4 } & Normokromik & 32 & 100,0 \\
\hline Kelainan bentuk eritrosit & Ada & 0 & 0,0 \\
\cline { 2 - 4 } & Tidak & 32 & 100,0 \\
\hline Basophilic stipling & Ada & 0 & 0,0 \\
\cline { 2 - 4 } & Tidak & 32 & 100,0 \\
\hline
\end{tabular}

Keberadaan $\mathrm{Pb}$ di dalam eritrosit menyebabkan terganggunya pembentukan hemoglobin dalam eritrosit. Pada sediaan hapus darah tepi keracunan $\mathrm{Pb}$ dapat dilihat dengan adanya benda inklusi eritrosit (basophilic stippling). Basophilic stippling adalah sisa agregat dari gagalnya pembentukan hemoglobin. ${ }^{9,21}$ Pemeriksaan menggunakan hapusan darah (Tabel 4) menunjukan responden tidak mengalami kelainan ukuran, warna, bentuk, dan tidak ditemukan Basophilic stipling. Hal tersebut sejalan dengan penelitian lain bahwa tidak ditemukan Basophilic stipling pada responden tukang ojek di wilayah ciamis. Hal tersebut terjadi karena efek paparan 
Prasetya, H.R., dkk: Hubungan Timbal Darah terhadap Kelainan Sel Darah pada Anak Jalanan di Kota Yogyakarta

timbal belum bisa mempengaruhi sel-sel darah sehingga belum bisa ditemukan adanya Basophilic stipling. ${ }^{22}$ Paparan $\mathrm{Pb}$ yang didapat belum menyebabkan defisiensi enzim G-6PD dan penghambatan enzim pirimidin-5'-nukleotidase sehingga tidak dapat meimbulkan kelainan basophilic stippling pada eritosit.

Tabel 5. Uji hubungan timbal darah dengan darah lengkap

\begin{tabular}{ccl}
\hline Variabel & P & Keterangan \\
\hline Hemoglobin & 0,252 & Tidak terdapat hubungan \\
\hline Eritrosit & 0,462 & Tidak terdapat hubungan \\
\hline Trombosit & 0,268 & Tidak terdapat hubungan \\
\hline Leukosit & 0,272 & Tidak terdapat hubungan \\
\hline Hematokrit & 0,364 & Tidak terdapat hubungan \\
\hline Netrofil & 0,543 & Tidak terdapat hubungan \\
\hline Limfosit & 0,497 & Tidak terdapat hubungan \\
\hline Monosit & 0,997 & Tidak terdapat hubungan \\
\hline Eosinofil & 0,377 & Tidak terdapat hubungan \\
\hline Basofil & 0,822 & Tidak terdapat hubungan \\
\hline
\end{tabular}

Hasil uji statistik (Tabel 5) menunjukan tidak terdapat hubungan antara timbal darah dengan profil darah. Hal ini disebabkan karena hasil timbal darah dan profil darah berada pada rentang normal. Hal tersebut sejalan dengan penelitian yang pernah dilakukan tahun 2016, dimana tidak terdapat hubungan yang bermakna antara kadar timbal darah dengan jumlah eritrosit. ${ }^{19}$

\section{KESIMPULAN}

Tidak terdapat hubungan antara timbal darah dengan kuantitas sel darah. Pada pemeriksaan Morfologi sel darah tidak ditemukan kelainan sel dan tidak ditemukan basophilic stippling. Meskipun terpapar asap kendaraan setiap hari, responden anak jalanan tidak mengalami keracunan timbal dan tidak mengalami kelainan sel darah. Penelitian selanjutnya perlu dilakukan dengan responden dengan masa terpapar timbal lebih dari 5 tahun. Selain itu dapat dilakukan penelitian dengan responden anak-anak/lansia yang bekerja di pinggir jalan.

\section{UCAPAN TERIMAKASIH}

Penulis mengucapkan terimakasih kepada KEMENRISTEK DIKTI yang telah memberikan dana untuk penelitian ini melalui hibah penelitian dosen.

\section{DAFTAR PUSTAKA}

1. Sengkey SL, Jansen F, Wallah S. TINGKAT PENCEMARAN UDARA CO AKIBAT LALU LINTAS DENGAN MODEL PREDIKSI POLUSI UDARA SKALA MIKRO. Vol 1.; 2011. 
Prasetya, H.R., dkk: Hubungan Timbal Darah terhadap Kelainan Sel Darah pada Anak Jalanan di Kota Yogyakarta

2. WHO. Childhood lead poisoning. childhold Lead Poisioning. 2010.

3. Popescu CG. Relation Between Vehicle Traffic And Heavy Metals Content From The Particulate Matters. Rom Reports Phys. 2011;63(2):477482.

4. Wantara IA. Analisis Jumlah Kendaraan Bermotor Di Daerah Istimewa Yogyakarta (1990Â€“"2012). Kinerja. 2017;19(1):68. doi:10.24002/kinerja.v19i1.535

5. BPS Provinsi D.I. Yogyakarta. https://yogyakarta.bps.go.id/dynamicta ble/2018/02/01/109/jumlah-kendaraanbermotor-yang-terdaftar-menurutjenisnya-di-d-i-yogyakarta.html. Accessed May 26, 2021.

6. Ruslinda Y, Gunawan H, Goembira F, Wulandari S. Pengaruh Jumlah Kendaraan Berbahan Bakar Bensin terhadap Konsentrasi Timbal ( $\mathrm{Pb}$ ) di Udara Ambien Jalan Raya Kota Padang. Semin Nas Sains dan Teknol Lingkung II. 2016:162.

7. Karrari P, Mehrpour O, Abdollahi M. A systematic review on status of lead pollution and toxicity in Iran; Guidance for preventive measures. DARU, J Pharm Sci. 2012;20(1):1-17. doi:10.1186/1560-8115-20-2

8. Maleknejad S, Heidarzadeh A, Rahbar M, Safaei A, Ghomashpasand B. Evaluation of serum lead levels in children with constipation and normal controls in northern iran. Iran $J$ Pediatr. 2013;23(4):417-422. http://www.ncbi.nlm.nih.gov/pubmed/ 24427495. Accessed May 26, 2021.

9. Robert M Kliehman, BonitF Stanton, Nina F Schor, Richard E. Behrman JWSG. Nelson Textbook of Padetrician.; 2011. WWW.mdconsults.com/books/about.d o.

10. Aulia Rahman A. GAMBARAN KADAR TIMBAL (PB) DALAM DARAH TUKANG PARKIR PASAR BANJARBARU MARET 2017. Akad Kesehat Borneo Lestari Banjarbaru. September 2017.

11. Kustiningsih Y, Fitriyanti N, Nurlailah
N. Kadar Logam Timbal $(\mathrm{Pb})$ dalam Darah Penjual Klepon. Med Lab

Technol J. 2017;3(2):47.
doi:10.31964/mltj.v3i2.168

12. Muliyadi M. PAPARAN TIMBAL UDARA TERHADAP TIMBAL DARAH, HEMOGLOBIN, CYSTATIN C SERUM PEKERJA PENGECATAN MOBIL. $J$ Kesehat Masy. 2015;11(1):87. doi:10.15294/kemas.v11i1.3519

13. Rizkiawati A. FAKTOR-FAKTOR YANG BERHUBUNGAN DENGAN KADAR HEMOBLOBIN ( $\mathrm{Hb})$ DALAM DARAH PADA TUKANG BECAK DI PASAR MRANGGEN DEMAK. $J$ Kesehat Masy Univ Diponegoro. 2012;2(1):663-669.

14. Sari BT, Lubis B. Hubungan antara keracunan timbal dengan anemia defisiensi besi pada anak. Maj Kedokt Nusant. 2014;47(3):164-167.

15. Pratiwi L. Perbedaan Kadar Hemoglobin Darah Pada Kelompok Polisi Lalu Lintas Yang Terpapar Dan Tidak Terpapar Timbal Di Wilayah Polres Jakarta Selatan. J Kesehat Masy. 2012;1(2):738 - 749.

16. Makawekes MT, Kalangi SJR, Pasiak TF. PERBANDINGAN KADAR HEMOGLOBIN DARAH PADA PRIA PEROKOK DAN BUKAN PEROKOK. J e-Biomedik. 2016;4(1). doi:10.35790/ebm.4.1.2016.11250

17. Pahlawan SD, Keman S. Korelasi Kadar Plumbum Darah Dengan Kadar Hemoglobin Dan Hematokrit. $J$ Kesehat Lingkung. 2014; Vol 7 No 2:159-165.

18. Ardillah Y. Faktor Risiko Kandungan Timbal Di Dalam Darah. J Ilmu Kesehat Masy. 2016;7(3):150-155.

19. Maskinah EM. HUBUNGAN KADAR TIMBAL DALAM DARAH DENGAN JUMLAH ERITROSIT PADA SISWA SEKOLAH DASAR (Studi di SD Negeri Grinting 01 Kecamatan Bulakamba Kabupaten Brebes Jawa Tengah). J Kesehat Lingkung Indones. 2017;15(2):42. doi:10.14710/jkli.15.2.42-45 
Prasetya, H.R., dkk: Hubungan Timbal Darah terhadap Kelainan Sel Darah pada Anak Jalanan di Kota Yogyakarta

20. Prasetya HR, Rahadian TD. Gambaran Indeks Eritrosit Pada Anak Jalanan Di Kota Yogyakarta. J Heal. 2018;6(1):12-15.

21. Kumar R. Abnormal Scenes in a Blood Film. Hematol Transfus Int $J$. 2016;2(6).

doi:10.15406/htij.2016.02.00055

22. Rohayati, Edhiatmi M, Afrilia FM. Pemeriksaan Sel Basophilic Stippling Pada Tukang Ojek Di Pasar Ciamis Tahun 2016. Vol 4.; 2016. 